\title{
Influence of low molecular weight compounds associated to cashew (Anacardium occidentale L.) fiber on lipid metabolism, glycemia and insulinemia of normal mice
}

\author{
Diana Valesca Carvalho ${ }^{\mathrm{a}}$, Flávia Almeida Santos ${ }^{\mathrm{b}}$, Renan Pereira de Lima ${ }^{\mathrm{c}}$, \\ Ana Flávia Seraine Custódio Viana ${ }^{\mathrm{b}}$, Said Gonçalves Cruz Fonseca ${ }^{\mathrm{d}}$, Paulo Iury Gomes Nunes ${ }^{\mathrm{b}}$, \\ Tiago Sousa de Melo ${ }^{\mathrm{e}}$, Maria Izabel Gallão ${ }^{\mathrm{f}}$, Edy Sousa de Brito ${ }^{\mathrm{g}, *}$ \\ a Instituto de Cultura e Arte, Universidade Federal do Ceará, Fortaleza, CE, Brazil \\ b Departamento de Fisiologia e Farmacologia, Faculdade de Medicina, Fortaleza, CE, Brazil \\ ${ }^{\mathrm{c}}$ Faculdade de Farmácia, Universidade de Fortaleza, Fortaleza, CE, Brazil \\ d Departamento de Farmácia, Faculdade de Farmácia, Odontologia e Enfermagem, Universidade Federal do Ceará, Fortaleza, CE, Brazil \\ e Faculdade de Farmácia, Instituto Superior de Teologia Aplicada, Sobral, CE, Brazil \\ ${ }^{\mathrm{f}}$ Departamento de Biologia, Universidade Federal do Ceará, Fortaleza, CE, Brazil \\ ${ }^{g}$ Embrapa Agroindústria Tropical, R Dra Sara Mesquita, 2270, Pici, 60511-110 Fortaleza, CE, Brazil
}

\section{A R T I C L E I N F O}

\section{Keywords:}

Abdominal fat

Dietary fiber

Fruit

Insulin

Obesity

\begin{abstract}
A B S T R A C T
The objective of this study was to evaluate the effect of cashew fiber wheter or not associated with low molecular weight compounds on lipid profile, abdominal adiposity, glycemia and insulinemia and serum concentration of ghrelin and leptin hormones from normal mice. We evaluated the cashew fiber in its integral form (IcF) and the cashew fiber after being submitted to the process of extraction of low molecular weight metabolites (cFSM). The two fibers were incorporated into the feed of male Swiss mice for 15 weeks. At the end of the treatment, blood glucose, total cholesterol and fractions, triglycerides, urea, AST, ALT, hormone levels of insulin, leptin and ghrelin were analyzed, as well as GSH and hepatic MDA. The consumption of cFSM diet promoted reduction of glycemia, insulin and ghrelin. Animals fed the IcF diet showed hyperlipidemia, hyperleptinemia and increased abdominal fat. In addition, no changes were observed in the lipid profile of the animals, in the abdominal adiposity and in the leptin hormone in the group that received cFSM diet. We conclude that the removal of small molecules is fundamental to use cashew fiber as a functional food with possible health benefits.
\end{abstract}

\section{Introduction}

Dietary fiber has a major role in nutrition and health, reducing risk factors associated in the development of various chronic diseases, such as obesity, cardiovascular disease and type 2 diabetes, by promoting weight, blood glucose and lipid profile reduction (American Ditetic Association, 2008). Fiber is the most used ingredient in the elaboration of functional foods, representing more than $50 \%$ of the total ingredients on the market. Fiber products are also expanding as a dietary and pharmacological supplement (Saura-Calixto, 2006). In this context, fruit by-products from industrial processes are potential sources of dietary fiber that can be incorporated into food products or used in the manufacture of supplements (Mildner-Szkudlarz et al., 2016; Tańska et al., 2016).
Compared with the dietary fiber of cereals, fruit fiber is reported to have a better quality due to its higher content of total and soluble fibers, water and oil retention capacity and colon fermentability, as well as its lower levels of phytic acid and caloric value (Zhang et al., 2017). In addition, fruit fiber has significant amounts of secondary compounds associated with it, such as polyphenols and other bioactive compounds (Martín-Carrón, Goñi, Larrauri, García-Alonso, \& Saura-Calixto, 1999). Studies have determined that fruit bagasse could be used as a potential food ingredient to develop healthy, safe, tasty, sustainable and socially acceptable food products. This is mainly due given that fruit bagasse is rich in total dietary fiber with high content in phenolic compounds and flavonoids that provide interesting technological and antioxidants properties (Cerda-Tapia, Pérez-Chabela, Pérez-Álvarez, FernándezLópez, \& Viuda-Martos, 2015; Mildner-Szkudlarz et al., 2016; Tańska

\footnotetext{
* Corresponding author.

E-mail addresses: dianacarvalhoufc@gmail.com (D.V. Carvalho), fasufc@gmail.com (F.A. Santos), renan1647@edu.unifor.br (R.P. de Lima), said@ufc.br (S.G.C. Fonseca), tiagosousam@gmail.com (T.S. de Melo), izabelgallao@ufc.br (M.I. Gallão), edy.brito@embrapa.br (E.S. de Brito).
} 
Table 1

Proximate composition of the Integral Cashew Fiber (IcF), the Cashew Fiber without low molecular weight metabolites (cFSM), the ND + IcF (10\%) and the ND + cFSM (10\%).

\begin{tabular}{|c|c|c|c|c|c|c|c|}
\hline Amostra & Humidity \% & Fat $\%$ & Protein \% & Ash \% & Carbohydrates \% & Energy (kcal/100 g) & Fiber $\%$ \\
\hline IcF & 4.4 & 3.0 & 12.3 & 1.8 & 78.4 & 390.2 & 13.1 \\
\hline cFSM & 14.1 & 0.7 & 13.3 & 1.1 & 70.8 & 342.6 & 11.6 \\
\hline $\mathrm{ND}+\mathrm{IcF}(10 \%)$ & 7.8 & 4.8 & 21.4 & 6.8 & 59.2 & 365.6 & 5.3 \\
\hline $\mathrm{ND}+\mathrm{cFSM}(10 \%)$ & 7.0 & 3.7 & 21.6 & 6.7 & 60.9 & 363.7 & 4.6 \\
\hline
\end{tabular}

ND - normal diet.

et al., 2016).

Research of rats fed an isocaloric diet demonstrate biological properties of apple pomace, orange bagasse and passion fruit peel as alternative sources of dietary fiber. The results suggest that fruit byproducts have a positive influence on lipid and glucose metabolism, promoting a significant reduction in triglycerides and hepatic cholesterol serum levels; they also showed important effects in the control of post prandial glucose (Macagnan et al., 2015).

The in vivo studies (Lecumberri et al., 2007; Martín-Carrón et al., 1999) and human trials (Pérez-Jiménez et al., 2008) have evaluated the effect of non-extractable polyphenols associated with fiber on intestinal health and the risks of cardiovascular diseases. Studies refer to cocoa fiber, bagasse and grape seed and the antioxidant dietary fiber of the grape. In relation to cardiovascular diseases, animal studies have demonstrated a reduction in lipid peroxidation, reduction of cholesterol, LDL and triglycerides, as well as atherogenic index reduction, as well as increased stool weight and increased excretion of protein and fat in feces (Lecumberri et al., 2007; Martín-Carrón et al., 1999). Tests in humans also showed a significant reduction of cholesterol and LDL, reduced risk of cardiovascular disease, and reduced blood pressure (Pérez-Jiménez et al., 2008).

Among the fruits with high fiber content, we can mention the cashew apple for its richness in nutrients and socioeconomic importance for Africa, India, Vietnam and Brazil. Cashew bagasse, a byproduct of peduncle processing, has high dietary fiber content, as well as antioxidant compounds ( Rufino et al., 2010). Cashew bagasse has been employed in the manufacture of different products such as cereal bars (de Oliveira, Malta, de Jesus, Cruz, \& Cardoso, 2013), hamburgers (Lima, 2008), biscuits (de Santana \& Silva, 2008) or simply dehydrated and grinded, constituting a raw material used in blends with cereal flours (Barros et al., 2012). However, there is a lack of scientific evidence on what are the specific health benefits of cashew bagasse fiber consumption. There are also no in vivo studies on the physiological effect of cashew bagasse fiber that guarantee its effectiveness in dietary prescription of a healthy diet. It should also be noted that the American Dietetic Association (2008) recommends looking for physiological efficacy studies before selecting functional fibers in dietetic practice.

The objective of this study was to evaluate the physiological effect of cashew fiber on the lipid profile, abdominal adiposity, glycemia and insulinemia, and the serum concentration of ghrelin and leptin hormones from normal mice. The cashew fiber was evaluated in its integral form, refered so forth as Integral Cashew Fiber (IcF) and the fiber after being submitted to the process of extraction of low molecular weight metabolites (fatty acids, waxes, pigments, sugars and phenolic compounds), refered as Cashew Fiber without Low Molecular Weight Metabolites (cFSM).

\section{Materials and methods}

\subsection{Integral Cashew Fiber (IcF)}

Cashew bagasse, obtained after the extraction of cashew juice, came from the juice industry Natvita located in the state of Ceará, Brazil. Approximately $300 \mathrm{~g}$ of cashew bagasse was immersed in water (1: 2, $\mathrm{w} / \mathrm{v}$ ) and exposed to ultrasonic waves using an Ultrasonic Cleaner 1450
USC (THORNTON / UNIQUE) for $1 \mathrm{~h}$. The fiber was drained, frozen $\left(-80^{\circ} \mathrm{C}\right)$ and freezedryed. The dried fiber was ground in a willye-type mill with a mesh of $0.595 \mathrm{~mm}$ in diameter, obtaining the integral cashew fiber (IcF).

\subsection{Cashew fiber without low molecular weight metabolites (cFSM)}

The IcF was subjected to sequential extraction with organic solvents (hexane and methanol) resulting in cashew fiber without low molecular weight metabolites (cFSM). Approximately $100 \mathrm{~g}$ of the IcF powder was extracted with hexane to remove the fatty acids, waxes and pigments in the proportion of $1: 12(\mathrm{~m} / \mathrm{v})$, in a soxhlet for $8 \mathrm{~h}$. Subsequently, an extraction with methanol was carried out to remove the low molecular weight phenolic compounds and sugars, in the ratio of $1: 12(\mathrm{~m} / \mathrm{v})$, in soxhlet for $72 \mathrm{~h}$. The residue obtained from this extraction was left in the hood $(72 \mathrm{~h})$ to a complete evaporation of the residual solvent and grinded on a mortar, resulting in cFSM. The cFSM obtained was stored under refrigeration until the feed formulation. The proximal composition of the IcF and cFSM fibers are shown in Table 1.

\subsection{Scanning electron microscopy (SEM)}

The morphology of IcF and cFSM was observed by scanning electron microscopy (SEM) using a TM-3000 tabletop microscope (Hitachi, Japan). Prior to the observation, samples were stuck on stubs with double-face tape and coated with a gold palladium layer. The determination was performed at an accelerating voltage of $15 \mathrm{kV}$.

\subsection{Diet composition}

Experimental diets were prepared by mixing IcF or cFSM with a normal diet (ND). The ND used was a pelleted feed obtained from a commercial source (Nuvilab, Colombo, PR, Brazil). By weight it consisted of: Humidity (max.) $12.5 \mathrm{~g} / 100 \mathrm{~g}$ - Total Protein (min.) $22 \mathrm{~g} /$ $100 \mathrm{~g}$ - Ethereal extrac (min.) $5 \mathrm{~g} / 100 \mathrm{~g}$ - Minerals (max.) $9 \mathrm{~g} / 100 \mathrm{~g}$ Fiber (max.) $7 \mathrm{~g} / 100 \mathrm{~g}$ - Calcium (min-max.) 1 a $1.4 \mathrm{~g} / 100 \mathrm{~g}$ Phosphorus (min.) $600 \mathrm{mg} / 100 \mathrm{~g}$. The ND was supplemented with $10 \%$ (dry weight) of IcF or cFSM. The proximate composition of the ND feed added IcF (10\%) and cFSM (10\%) are shown in Table 1.

\subsection{Animals}

Male Swiss albino mice ( $\mathrm{n}=10 /$ group), weighing between 19-23 g, from the Nucleus of Experimental Biology (NUBEX) of the University of Fortaleza (UNIFOR) were used. Throughout the experimental period, the animals remained in controlled conditions of light $\left(12 \mathrm{~h} \mathrm{light}-12 \mathrm{~h}\right.$ dark) and average temperature of $23-24^{\circ} \mathrm{C}$, humidity $55 \pm 5 \%$, receiving water and food (chow) ad libitum. The Federal University of Ceará Institutional Committee on Care and Use of Animals approved experimental protocols (number 21/15) for experimentation, in accordance with the guidelines of the National Institutes of Health, Bethesda, MD. 
Table 2

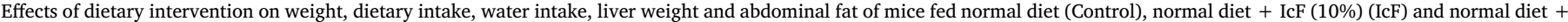
cFSM (10\%) (cFSM) for 15 weeks.

\begin{tabular}{|c|c|c|c|}
\hline Group & ND (Control) & $\mathrm{ND}+\mathrm{IcF}(10 \%)(\mathrm{IcF})$ & $\mathrm{ND}+\operatorname{cFSM}(10 \%)(\mathrm{cFSM})$ \\
\hline Body weight - initial (g) & $19.70 \pm 1.03$ & $19.80 \pm 0.99$ & $19.90 \pm 0.97$ \\
\hline Body weight - final (g) & $48.10 \pm 1.91$ & $49.89 \pm 1.32$ & $47.80 \pm 1.11$ \\
\hline Feed intake (g/week) & $48.96 \pm 1.44$ & $46.94 \pm 1.54$ & $47.54 \pm 1.79$ \\
\hline Net energy intake (kcal/mouse/day) & $22.95 \pm 0.68$ & $24.52 \pm 0.80$ & $24.71 \pm 0.93$ \\
\hline Water intake $(\mathrm{mL} /$ week $)$ & $62.17 \pm 2.24$ & $66.64 \pm 3.04$ & $85.65 \pm 5.67^{* * *}$ \\
\hline Liver wt (mg/10 g of body wt) & $435.20 \pm 7.63$ & $433.90 \pm 7.19$ & $423.40 \pm 3.97$ \\
\hline Abdominal fat (mg/10 $\mathrm{g}$ of body wt) & $238.0 \pm 24.48$ & $385.0 \pm 64.60$ & $181.0 \pm 22.04$ \\
\hline
\end{tabular}

The results are expressed as mean \pm standard error.

$* p<0.05$ versus control.

$* * p<0.001$ versus control.

\subsection{Experimental protocol}

The animals were randomly divided into three experimental groups ( $n=10):$ i) The control group, fed the normal diet (ND), ii) The IcF group, fed the ND + IcF (10\%), iii) The cFSM group, fed the ND + cFSM (10\%).

The body weight of each mouse was measured once a week, the total amount of food consumption was recorded every day for 15 weeks, and weekly consumption of food ( $\mathrm{g} /$ week) and water (mL/ week) ad libidum was recorded. Energy intake (kcal/mouse/day) was also evaluated during the 15 weeks of feeding trial. At the end of this period, animals were starved for $6 \mathrm{~h}$, where blood samples were taken by venous puncture under light anestesia with diethyl ether, and then sacrificed by cervical dislocation. The serum was used within a few hours or frozen at $-70^{\circ} \mathrm{C}$ until analysis. The liver and abdominal adipose tissues were dissected, weighed, and expressed in milligrams per $10 \mathrm{~g}$ body weight.

\subsection{Biochemical analysis}

Serum concentrations of glucose, triglycerides, total cholesterol and urea were analyzed using comercial kits (Labtest, Minas Gerais, Brazil), and the levels were expressed in milligrams per decilitre. Serum concentrations of low-density lipoprotein (LDL-c) and very low-density lipoprotein (VLDL-c) were calculated using the Friedewald, Levy, and Fredrickson (1972) formula to which LDL-c $=$ TC - (HDL-c + VLDL-c) and VLDL-c $=\mathrm{TG} / 5$. Serum levels of alanine amino transferase (ALT) and aspartate amino transferase (AST) activities expressed in units per liter were analyzed by a kinetic method using commercial kits (Labtest, Minas Gerais, Brazil). Serum levels of insulin (Sigma-Aldrich), leptina (Millipore), ghrelin (Sigma-Aldrich) were measured by enzyme-linked immunosorbent assay (ELISA) performed in duplicate and expressed in $\mathrm{pg} / \mathrm{mL}$ or $\mu \mathrm{IU} / \mathrm{mL}$.

\subsection{Evaluation of hepatic tissue}

\subsubsection{Assessment of lipid peroxidation}

Hepatocyte lipoperoxidation was measured according to the method of Ohkawa, Ohishi, and Yagi (1979). This method evaluates oxidative stress by the quantification of malondialdehyde (MDA), which is the last product of lipid breakdown caused by oxidative stress that generates lipid peroxidation. Lipid peroxidation was assessed by spectrophotometry and the production of MDA was determined and expressed as nmoL/g tissue.

\subsubsection{Determination of non-protein sulfhydryl groups}

Liver samples were weighed and homogenized with ice-cold $0.02 \mathrm{M}$ EDTA to prepare a $10 \%$ homogenate. It was then added to a $1 \mathrm{~mL}$ aliquot of the homogenate, $0.8 \mathrm{~mL}$ of distilled water and $0.2 \mathrm{~mL}$ of $50 \%$ trichloroacetic acid, the samples were then centrifuged at $3000 \mathrm{~g}$ for
$15 \mathrm{~min}$. A volume of $1 \mathrm{~mL}$ was withdrawn from the supernatant and $2 \mathrm{~mL}$ of Tris buffer $(0.4 \mathrm{M}, \mathrm{pH} 8.9)$ and $50 \mu \mathrm{L}$ of $0.01 \mathrm{M}$ DTNB were added. The absorbance was measured within $5 \mathrm{~min}$ at $412 \mathrm{~nm}$. The concentration of the non-protein sulfhydryl groups (NP-SH) was calculated by a reduced glutathione standard curve (GSH) and the results were expressed as $\mu \mathrm{g}$ NP-SH/mg tissue (Sedlak \& Lindsay, 1968).

\subsection{Histological analysis}

The liver was fixed in formaldehyde (10\%) for $24 \mathrm{~h}$ and transferred to an alcohol (70\%) solution, where the material was conditioned until the sections were made. For preparation of the material, the dehydration and inclusion of the samples in Historesin Leica were performed. A $5 \mu \mathrm{m}$ cut was obtained and then stained with Hematoxylin-Eosin (HE). The image acquisition was performed under a light microscope (Model BX41, Olympus Optical) coupled to a digital camera (Model UC30) and a computer, using the "CELL" software.

\subsection{Statistical analysis}

Results were expressed as mean \pm standard error of the mean, using one-way analysis of variance (ANOVA) followed by the Tukey test using the GraphPad Prism 5.0 statistical analysis software (GraphPad Sotware, Inc., San Diego, CA, USA). Values of $P<0.05$ were considered statistically significant.

\section{Results and discussion}

\subsection{Effects of IcF and cFSM on food intake, water intake, liver weight and abdominal fat}

At the end of week 15 the cFSM group showed a significant increase $(P<0.01)$ in water intake when compared to the control group (Table 2). Most likely the removal of the metabolites (sugar, carotenoids and wax) left the fiber exposed (Fig. 1), turning the fiber available for the solid-liquid interaction, which may have potentiated the water absorption by the fiber. Water absorption capacity is an important property both from the physiological and technological point of view, since it can increase the volume of food and modify the viscosity and texture of a formulated product. From the physiological point of view, water absorption capacity is an important property for weight loss and digestive health (Zhang et al., 2017).

The data showed a significant difference in the amount of abdominal fat of the IcF group when compared to the control $(P<0.01)$ (Table 2). The IcF promoted increased abdominal fat in the animals, even in the presence of an isocaloric diet. However, the removal of the low molecular weight metabolites of the cashew fiber prevented abdominal fat gain of normal mice. This effect may be associated with the type of carbohydrate, particularly sugars, which was extracted by the use of methanol, since the proximal composition of the two diets (ND + 

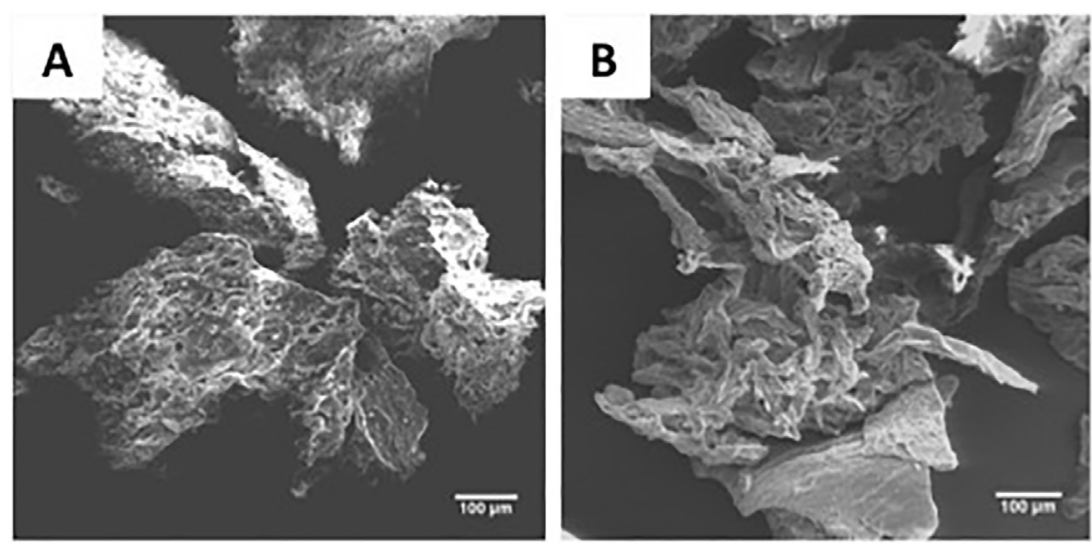

Fig. 1. Electronic photomicrography of cashew fiber: A) Integral Cashew Fiber ( IcF); B) Cashew Fiber without Low Molecular Weight Metabolites (cFSM).
IcF and ND + cFSM) was similar (Table 1) and there were no difference in energy consumption among groups (Table 2). In addition, the largest difference in the proximal composition between IcF and CFSM was the percentage of carbohydrates, $78.43 \%$ and $70.81 \%$, respectively (Table 1). Usually, fruits are rich in reducing sugars (glucose and fructose). Fructose alone is poorly absorbed, but absorption is increased by the presence of glucose in the intestine, with rapid and complete absorption of both fructose and glucose. In addition, fructose is preferentially metabolized to lipids in the liver, leading to an increase in triglyceride levels, which are associated with the development of insulin resistance and cardiovascular disease (Stanhope et al., 2009; Tappy, Lê, Tran, \& Paquot, 2010; Wei, Wang, Topczewski, \& Pagliassotti, 2007).

There was no statistical difference in initial and final weight, food intake, energy consumption and liver weight among the three groups (Table 2). This result was already expected due to the use of isocaloric diet in the three studied groups. However, these results suggest that both cashew fibers do not interfere in the nutrient utilization of the feed and demonstrate that the consumption of these fibers allowed the normal development and growth of the animals, excluding the possibility of antinutritional effect.

\subsection{Effects of dietary intake of IcF and cFSM on serum parameters and hepatic tissue evaluation}

The diet with IcF increased plasma concentrations of AST (102\%), total cholesterol (45.6\%), LDL (62.1\%) and triglycerides (27.6\%) when compared to the normal diet. It is noteworthy that in our study the animals were submitted to a normal diet and that IcF exerted a hyperlipidemic effect even when added to an isocaloric diet. This hyperlipidemic effect may have occurred due to the presence of reducing sugars in IcF. Studies have shown that fructose consumption in the form of sucrose or sweetened beverages can have significant effects on the selective deposition of visceral and ectopic fat, lipid metabolism, lipogenesis, blood pressure, and insulin sensitivity (Stanhope et al., 2009; Tappy et al., 2010; Wei et al., 2007). Emphasizing that this study is not comparing cashew fiber to sweetened beverages, but comparing the type of nutrient present in both foods and their metabolism. However, IcF and CFSM were able to significantly reduce plasma ALT $(P<0.001$ and $P<0.01$, respectively) and glucose $(P<0.05$ and $P<0.01$, respectively) when compared to the control group (Table 3 ).

Glycemia reduction of the animals occurred with consumption of both fibers with a more pronounced effect of cFSM, even with predominance of insoluble fiber in its constitution and in the presence of an isocaloric diet. Cashew apple has a high content of dietary fiber $\left(209 \mathrm{~g} \mathrm{~kg}^{-1}\right.$ d.m.) with a predominance of insoluble fiber $(88 \%)$ ( Rufino et al., 2010). Both the insoluble and the soluble fibers are capable of decreasing the energy digestibility. This action is explained by the property of the insoluble fiber in accelerating the intestinal transit
Table 3

Effects of dietary intakes of ND + IcF (10\%) and ND + cFSM (10\%) on serum parameters and hepatic tissue evaluation of normal mice fed for 15 weeks.

\begin{tabular}{|c|c|c|c|}
\hline Group & ND (Control) & $\begin{array}{l}\mathrm{ND}+\mathrm{IcF}(10 \%) \\
(\mathrm{IcF})\end{array}$ & $\begin{array}{l}\mathrm{ND}+\mathrm{cFSM}(10 \%) \\
(\mathrm{cFSM})\end{array}$ \\
\hline AST (U/L) & $34.92 \pm 3.82$ & $70.54 \pm 12.27^{*}$ & $34.92 \pm 6.53$ \\
\hline ALT (U/L) & $49.52 \pm 2.44$ & $28.60 \pm 2.40^{*}$ & $35.60 \pm 2.51^{3 * x}$ \\
\hline $\begin{array}{l}\text { Liver total } \\
\text { cholesterol } \\
(\mathrm{mg} / \mathrm{g})\end{array}$ & $42.22 \pm 6.87$ & $67.95 \pm 3.17^{* *}$ & $52.90 \pm 2.97$ \\
\hline Glucose (mg/dL) & $119.00 \pm 9.90$ & $89.14 \pm 5.97^{*}$ & $73.53 \pm 5.30^{\text {k.k*k }}$ \\
\hline $\begin{array}{c}\text { Total cholesterol } \\
(\mathrm{mg} / \mathrm{dL})\end{array}$ & $84.56 \pm 6.72$ & $123.10 \pm 2.68^{* * * * k}$ & $93.63 \pm 3.92$ \\
\hline HDL (mg/dL) & $24.21 \pm 0.53$ & $22.07 \pm 0.79$ & $22.03 \pm 0.66$ \\
\hline $\mathrm{LDL}(\mathrm{mg} / \mathrm{dL})$ & $46.15 \pm 3.98$ & $74.81 \pm 4.08$ & $46.39 \pm 3.53$ \\
\hline VLDL (mg/dL) & $20.87 \pm 0.93$ & $23.42 \pm 1.31$ & $21.34 \pm 1.80$ \\
\hline $\begin{array}{l}\text { Tryglicerides (mg/ } \\
\text { dL) }\end{array}$ & $98.22 \pm 3.70$ & $125.30 \pm 8.42^{*}$ & $108.10 \pm 7.47$ \\
\hline Urea $(\mathrm{mg} / \mathrm{dL})$ & $65.08 \pm 3.11$ & $56.91 \pm 1.70$ & $73.50 \pm 2.75$ \\
\hline $\begin{array}{l}\text { MDA nmol/g } \\
\text { tissue }\end{array}$ & $23.30 \pm 1.10$ & $16.73 \pm 1.90$ & $19.10 \pm 3.00$ \\
\hline $\begin{array}{l}\text { NP-SH ( } \mu \mathrm{g} / \mathrm{mg} \\
\text { tissue) }\end{array}$ & $1.40 \pm 0.10$ & $1.90 \pm 0.20$ & $1.30 \pm 0.10$ \\
\hline
\end{tabular}

The results are expressed as mean \pm standard error.

$* p<0,05$ versus control.

$* * p<0,01$ versus control.

$* * * * 0<0001$ versus control.

time, by the lower activity of the pancreatic enzymes, by greater difficulty for the diffusion of enzymes and nutrients, and a lower enzymesubstrate interaction, due to the physical barrier presented by the plant cell wall (Pak \& Araya, 2001). The more pronounced effect of cFSM on the reduction of glycemia may have been due to the withdrawal of the low molecular weight metabolites present in IcF, mainly sugars. In addition, cFSM was more exposed (Fig. 1) and this may have potentiated the physiological effect of the fiber.

Fruit fibers failed to promote weight reduction and beneficial effects on the metabolism of carbohydrates and lipids (Bajerska, Chmurzynska, Mildner-Szkudlarz, \& Drzymała-Czyz, 2015; Ojo et al., 2016). In addition, the report of the Scientific Advisory Committee on Nutrition (2015) states that no significant association was found between fruit fiber intake and cardiovascular disease, as well as coronary events. However, there are positive effects in reducing serum cholesterol and triglycerides concentrations when fruit fiber is subjected to some technological process, such as micronization, potentializing the physiological effects of fiber (Wang et al., 2007; Wu, Wu, \& Chau, 2009). Although in this study we did not use cashew fiber in the presence of a hyperlipidic diet, we observed that IcF altered the lipid profile of the animals and when the fiber was submitted to the withdrawal of the low molecular weight metabolites, this effect was absent, demonstrating an improvement of the physiological properties of the fiber. 

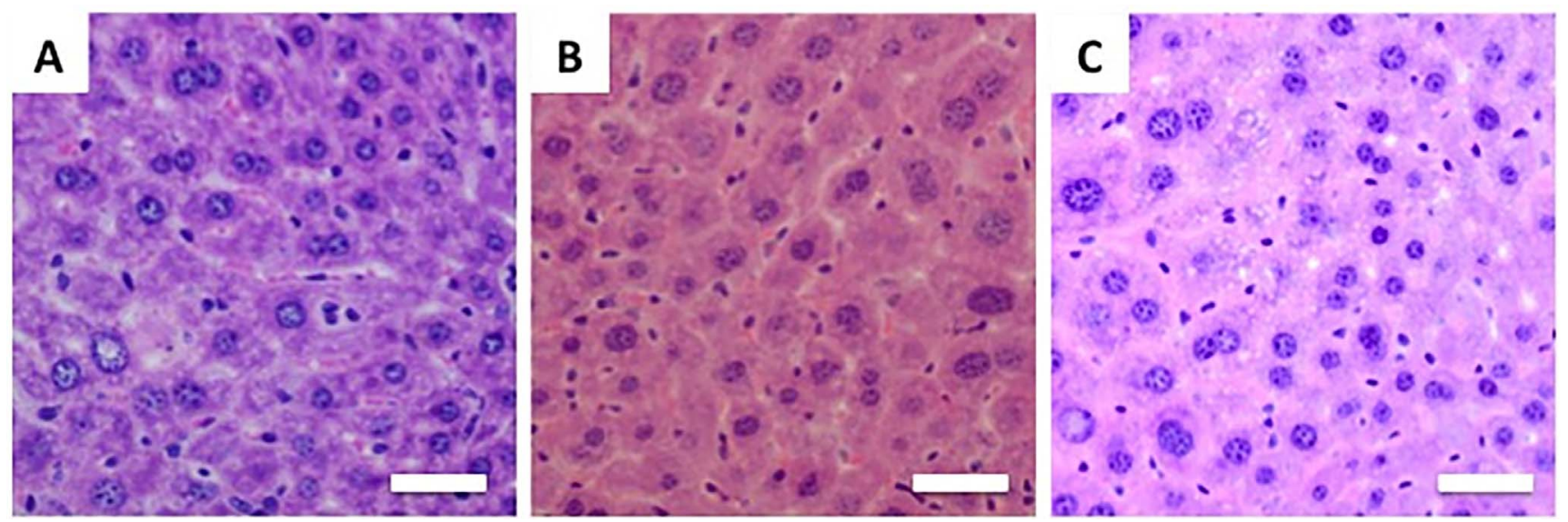

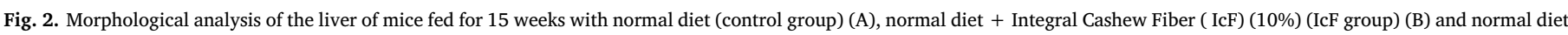
+ Cashew Fiber without Low Molecular Weight Metabolites (cFSM) (10\%) (cFSM group) (C). Bar $50 \mu \mathrm{m}$.

It was observed an absence of hepatic damage with cFSM consumption, indicated by the maintenance of the serum concentration of hepatic transaminase AST and reduction of ALT, in addition to absence of oxidative stress observed by MDA and GSH (NP-SH) (Table 3). The IcF did not promote oxidative stress, however, increased liver transaminase AST, but not ALT. This demonstrates a possible absence of hepatic damage with the consumption of the IcF. However, the increase of AST can be associated to the elevation of the serum lipids. These results are reinforced by the morphological analysis of the liver (Fig. 2). The images show that the hepatocytes of the control, IcF and cFSM groups have a rounded central nucleus with one or two well-evident nuclei arranged in an organized manner.

Transaminases are considered to be sensitive indicators of hepatocellular damage, providing a quantitative evaluation of liver damage (Muiller et al., 2013). Transaminase AST is usually found in a variety of tissues including the liver, heart, muscles, kidney, and brain. It is released into the blood when any of these tissues is compromised, and is therefore not a highly specific indicator of liver damage. Although, the ALT transaminase is found largely in the liver at high concentrations, it is not produced exclusively by this organ. The ALT is released into the bloodstream as the result of liver damage, being a specific indicator of liver injury (Schumann et al., 2002).

\subsection{Effects of IcF and cFSM intake on serum levels of leptin, insulin and ghrelin}

While mice fed the cFSM diet showed no change in serum leptin levels, those fed the IcF diet showed elevated leptin levels when compared to control group $(P<0.05)$. Plasma levels of insulin and ghrelin were significantly lower in the cFSM group when compared to the control group $(P<0.05)$ (Fig. 3).

The increase in plasma concentration of leptin with consumption of IcF was accompanied by accumulation of abdominal fat and alteration of the lipid profile of the animals. However, it is important to point out that the mice were submitted to an isocaloric diet and there were no differences in food intake and energy consumption among the three groups. Leptin is mainly produced in adipose tissue and its circulating levels are directly proportional to the amount of body fat, thus reflecting the state of energy storage in the long term (Considine et al., 1996). Leptin is highly implicated in the regulation of nutrient absorption, lipid metabolism and glucose homeostasis in adipose tissue, liver and skeletal muscle. However, leptin resistance is correlated with the development of obesity, and the desensitization found in obese individuals can affect the physiological regulation of lipids and glucose in adipose tissue, muscle and liver, as well as the use of nutrients in the gastrointestinal tract can contribute to the worsening of the obese state a)

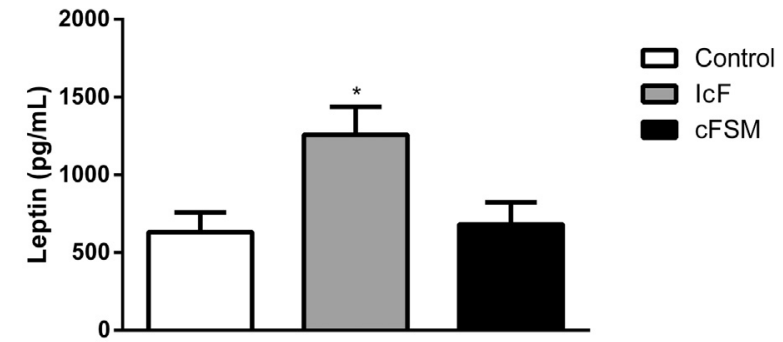

b)

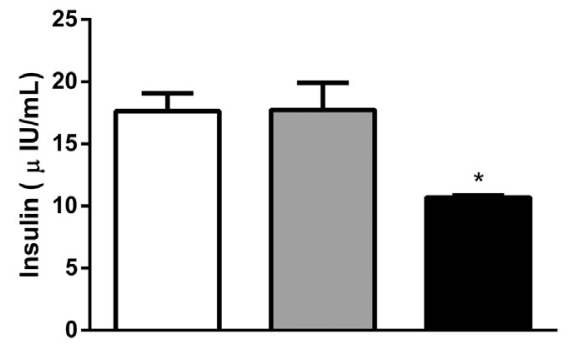

c)

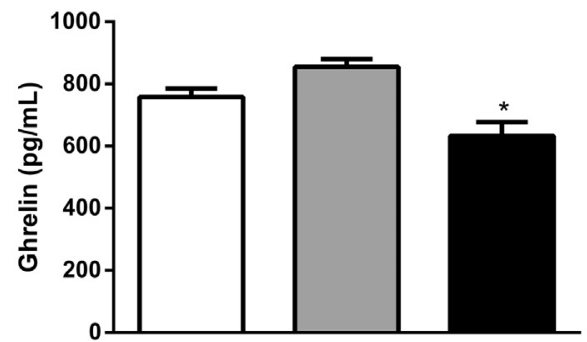

Fig. 3. Influence of cashew fiber on serum levels of leptin (a), insulin (b) and ghrelin (c) from mice fed normal diet (control group), normal diet + Integral Cashew Fiber (IcF) (10\%) (IcF group) and normal diet + Cashew Fiber without Low Molecular Weight Metabolites (cFSM) (10\%) (cFSM group) for 15 weeks. The results are expressed as mean \pm standard error of the mean $*(P<0.05)$ versus control.

\section{( Sáinz, Barrenetxe, Moreno-Aliaga, \& Martínez, 2015).}

Studies indicate that the presence of dietary fiber reduces the plasma leptin concomitantly with the decrease of corporal fat improving the metabolic health in hyperlipid diet-induced obese rats ( Adam et al., 2016; Lim, Goh, Mohtarrudin, \& Loh, 2016; Wang et al., 2007). As we did not induce obesity in our study, the expected result would be no change in leptin concentration in the IcF and cFSM groups. However, the hyperleptinemia verified with the consumption of IcF was consistent with the results of the abdominal adiposity and alteration of the lipid profile verified.

Regarding the reduction of insulinemia by cFSM, our hypothesis is 
that it is related to the pronounced reduction of glycemia with the consumption of this fiber, as seen previously. The hormone ghrelin was also reduced with the consumption of cFSM. Ghrelin is an appetite stimulating peptide that is released primarily by the stomach and gastrointestinal tract. It functions as a key modulator of energy homeostasis and plays an important role in the regulation of appetite, body weight, and glucose homeostasis. It equates the action of anorectic hormones and neuropeptides, such as leptin, peptide YY, GLP-1, cholecystokinin and CART ( Briggs, Enriori, Lemus, Cowley, \& Andrews, 2010). The dietary fiber consumption is associated to the reduction of ghrelin in obese animals induced by a hyperlipid diet supplemented with dietary fiber (Wang et al., 2007). Although our study did not observe the effects of dietary fiber with the use of a hyperlipid diet, cFSM reduced the serum concentration of ghrelin. This effect may be associated with a higher water intake observed in the cFSM consuming animals, due to the higher fiber exposure when the low molecular weight metabolites were withdrawn, enhancing this physiological effect even in the presence of isocaloric diet.

\section{Conclusions}

Integral cashew fiber (IcF) altered lipid metabolism, promoting hyperlipidemia, hyperleptinemia and increased abdominal fat in normal mice submitted to the isocaloric diet. This result leads us to believe that the enrichment incentive guidelines or the elaboration of products with cashew fiber should be carried out with caution, despite being a food rich in fibers and antioxidant compounds.

The extraction of the low molecular weight metabolites improved the physiological quality of the cashew fiber. The consumption of cashew fiber without low molecular weight metabolites (cFSM) in normal mice submitted to the isocaloric diet led to a reduction in glycemia, insulinemia and ghrelin hormone levels. In addition, no changes were observed in the lipid profile of the animals, in the abdominal adiposity and in the hormone leptin. Thus, cFSM can be used as a functional food with possible health benefits.

\section{Funding}

This work was supported by Instituto Nacional de Ciência e Tecnologia de Frutos Tropicais - INCT/CNPq, (465335/2014-4) and Conselho Nacional de Desenvolvimento Científico e Tecnológico, CNPq (474377/2013-0). The authors thank for the fund.

\section{Conflicts of interest}

None.

\section{References}

Adam, C., Gratz, S., Peinado, D., Thomson, L., Garden, K., Williams, P., \& Ross, A. (2016). Effects of dietary fibre (pectin) and/or increased protein (casein or pea) on satiety, body weight, adiposity and caecal fermentation in high fat diet-induced obese rats. PLoS One, 11(5), 1-16.

American Ditetic Association (2008). Position of the American dietetic Association: Health implications of dietary fiber. Journal of the American Dietetic Association, $1716-1731$.

Bajerska, J., Chmurzynska, A., Mildner-Szkudlarz, S., \& Drzymała-Czyz, S. (2015). Effect of rye bread enriched with tomato pomace on fat absorption and lipid metabolism in rats fed a high-fat diet. Journal of Science Food Agriculture, 95, 1918-1924.

Barros, N. D., Costa, N. Q., Porto, R. C., Morgano, M., Araújo, M. D., \& Moreira-Araújo, R. D. (2012). Elaboração de hamburger enriquecido com fibras de caju (Anacardium occidentale L.). B CEPPA, 30(2), 315-335.

Briggs, D., Enriori, P., Lemus, M., Cowley, M., \& Andrews, Z. (2010). Diet-induced obesity causes ghrelin resistance in arcuate NPY/AgRP neurons. Endocrinology, 151(10), 4745-4755.

Cerda-Tapia, A., Pérez-Chabela, M., Pérez-Álvarez, J.Á., Fernández-López, J., \& ViudaMartos, M. (2015). Valorization of pomace powder obtained from native mexican apple (Malus domestica var. rayada): Chemical, techno-functional and antioxidant properties. Plant Foods for Human Nutrition, 70, 310-316.

Considine, R., Sinha, M., Heiman, M., Kriauciunas, A., Stephens, T., Nyce, M., \& Caro, J.
(1996). Serum immunoreactive-leptin concentrations in normal-weight and obese humans. The New England Journal of Medicine, 334(5), 292-295.

Friedewald, W., Levy, R., \& Fredrickson, D. (1972). Estimation of the concentration of low-density lipoprotein cholesterol in plasma, without use of the preparative ultracentrifuge. Clinical Chemistry, 18(6), 499-502.

Lecumberri, E., Goya, L., Mateos, R., Alía, M., Ramos, S., Izquierdo-Pulido, M., \& Bravo, L. (2007). A diet rich in dietary fiber from cocoa improves lipid profile and reduces malondialdehyde in hypercholesterolemic rats. Nutrition, 23, 332-341.

Lim, S., Goh, Y., Mohtarrudin, N., \& Loh, S. (2016). Germinated brown rice ameliorates obesity in high-fat diet induced obese rats. BMC Complementary and Alternative Medicine, 16, 1-11.

Lima, J. R. (2008). Caracterização físico-química e sensorial de hambúrguer vegetal elaborado à base de caju. Ciência e Agrotecnologia, 32(1), 191-195.

Macagnan, F., dos Santos, L., Roberto, B., de Moura, F., Bizzani, M., \& da Silva, L. (2015). Biological properties of apple pomace, orange bagasse and passion fruit peel as alternative sources of dietary fibre. Bioactive Carbohydrates and Dietary Fibre, 6, 1-6.

Martín-Carrón, N., Goñi, I., Larrauri, J. A., García-Alonso, A., \& Saura-Calixto, F. (1999). Reduction in serum total and LDL cholesterol concentrations by a dietary fiber and polyphenol-rich grape product in hypercholesterolemic rats. Nutrition Research, 19, 1371-1381.

Mildner-Szkudlarz, S., Bajerska, J., Górnaś, P., Segliṇa, D., Pilarska, A., \& Jesionowski, T. (2016). Physical and Bioactive Properties of Muffins Enriched with Raspberry and Cranberry Pomace Powder: A Promising Application of Fruit By-Products Rich in Biocompounds. Plant Foods for Human Nutrition, 71, 165-173.

Müller, L. G., Pase, C. S., Reckziegel, P., Barcelosb, R. C., Boufleura, N., Pradod, A. C., \& Burgerb, M. E. (2013). Hepatoprotective effects of pecan nut shells on ethanol-induced liver damage. Experimental and Toxicologic Pathology, 65, 165-171.

Ohkawa, H., Ohishi, N., \& Yagi, K. (1979). Assay for lipid peroxides in animal tissues by thiobarbituric acid reaction. Analytical Biochemistry, 95(2), 351-358.

Ojo, B., El-Rassi, G., Payton, M., Perkins-Veazie, P., Clarke, S., Smith, B., \& Lucas, E. (2016). Mango Supplementation Modulates Gut Microbial Dysbiosis and Short-Chain Fatty Acid Production independent of body weight reduction in C57BL/6 micefFed a high-fat diet. The Journal of Nutrition, 1-9.

de Oliveira, C. F., Malta, H., de Jesus, M., Cruz, R., \& Cardoso, F. (2013). Desenvolvimento, avaliação sensorial e físico-química de barra de cereal de caju. Revista Brasileira Délelött Tecnologia Agroindustrial, 7(1), 934-942.

Pak, N., \& Araya, H. (2001). Fibra dietética y obesidad. In F. Lajolo, F. Saura-Calixto, E. Penna, E. Menezes, F. M. Lajolo, \& F. Saura-Calixto (Eds.). Fibra dietética en Iberoamérica: tecnología y salud (pp. 371-384). São Paulo: Varela.

Pérez-Jiménez, J., Serrano, J., Tabernero, M., Arranz, S., Díaz-Rubio, M., García-Diz, L., \& Saura-Calixto, F. (2008). Effects of grape antioxidant dietary fiber in cardiovascular disease risk factors. Nutrition, 24, 646-653.

Rufino, M., Pérez-Jiménez, J., Tabernero, M., Alves, R., de Brito, E., \& Saura-Calixto, F. (2010). Acerola and cashew apple as sources of antioxidants and dietary. International Journal of Food Science and Technology, 45, 2227-2233.

Sáinz, N., Barrenetxe, J., Moreno-Aliaga, M., \& Martínez, J. (2015). Leptin resistance and diet-induced obesity: Central. Metabolism Clinical and Experimental, 64, 35-46.

de Santana, M., \& Silva, L. (2008). Elaboração de biscoitos com resíduo da extração de suco de caju. Comunicado técnico 214 Embrapa Amazônia Oriental, 1, 1-4. Pará, Brasil: Belém.

Saura-Calixto, F. (2006). Evolución del concepto de fibra. In F. M. Lajolo, E. W. Menezes, F. M. Lajolo, \& E. W. Menezes (Eds.). Carbohidratos en Alimentos Regionales Iberoamericanos (pp. 235-254). São Paulo: Varela.

Schumann, G., Bonora, R., Ceriotti, F., Férard, G., Ferrero, C., Franck, P., \& Panteghini, M. (2002). IFCC primary reference procedures for the measurement of catalytic activity concentrations of enzymes at 37 degrees C. International Federation of clinical chemistry and laboratory medicine. Part 6 . Reference procedure for the measurement of catalytic con. Clinical Chemistry and Laboratory Medicine, 40(7), 734-738.

Scientific Advisory Committee on Nutrition (2015). Carbohydrates and health. London: The Stationery Office.

Sedlak, J., \& Lindsay, R. H. (1968). Estimation of total, protein-bound, and nonprotein sulfhydryl groups in tissue with Ellman's reagent. Analytical Biochemistry, 25 192-205.

Stanhope, K., Schwarz, J., Keim, N., Griffen, S., Bremer, A., Graham, J., \& Havel, P. (2009). Consuming fructose-sweetened, not glucose-sweetened, beverages increases visceral adiposity and lipids and decreases insulin sensitivity in overweight/obese humans. The Journal of Clinical Investigation, 119(5), 1322-1334.

Tańska, M., Roszkowska, B., Czaplicki, S., Borowska, E. J., Bojarska, J., \& Dabrowska, A (2016). Effect of Fruit Pomace Addition on Shortbread Cookies to Improve their Physical and Nutritional Values. Plant Foods for Human Nutrition, 71, 307-313.

Tappy, L., Lê, K., Tran, C., \& Paquot, N. (2010). Fructose and metabolic diseases: New findings, new questions. Nutrition, 26, 1044-1049.

Wang, Z., Zuberi, A., Zhang, X., Macgowan, J., Qin, J., Ye, X., \& Cefalu, W. (2007). Effects of dietary fibers on weight gain, carbohydrate metabolism, and gastric ghrelin gene expression in mice fed a high-fat diet. Metabolism Clinical and Experimental, 56, $1635-1642$.

Wei, Y., Wang, D., Topczewski, F., \& Pagliassotti, M. (2007). Fructose-mediated stress signaling in the liver: Implications for hepatic insulin resistance. Journal of Nutritional Biochemistry, 18, 1-9.

Wu, S.-C., Wu, S.-H., \& Chau, C.-F. (2009). Improvement of the hypocholesterolemic activities of two common fruit fibers by micronization processing. Journal of Agricultural and Food Chemistry, 57, 5610-5614.

Zhang, L., Zhu, M., Shi, T., Guo, C., Huang, Y., Chen, Y., \& Xie, M. (2017). Recovery of dietary fiber and polyphenol from grape juice pomace and evaluation of their functional properties and polyphenol compositions. Food and Function, 341-351. 